\title{
Cyert, March, and the Carnegie School
}

\section{Mie Augier}

The 'Carnegie School' is one of the important intellectual roots of TCE, at least (and in particular) as developed and practiced by Oliver Williamson, and Williamson has written about his Carnegie connections on several occasions (1996b, 2001). As he notes in the prologue to The Mechanisms of Governance (1996a), it was a direct result of his background as a student at Carnegie that he became interested in the idea of combining economics with organization theory, so central to today's transaction cost theory (Williamson, 1996a, p. 18). The interdisciplinary spirit was 'in the air' at Carnegie at that time. 'Those were exciting days', Williamson recalls. 'Orchestrating cutting-edge interdisciplinary research and teaching are never easy. ... [b]ut in the late 1950s and early 1960s, Carnegie was the place to be' (1996a, p. 21). The 'Carnegie School' is often identified with the pioneering work in Behavioral Economics done by Herbert Simon, James G. March and Richard Cyert in the 1950s and 1960s (Earl, 1988). The Carnegie behavioralists are known for their interest in understanding how individuals and organizations act and make decisions in the real world, and their challenges to the neoclassical theory of optimization and maximization in decision making and organizations. Concepts such as bounded rationality and satisficing were developed to describe individuals and organizations acting in the face of 'the uncertainties and ambiguities of life' (March and Simon, 1958, p. 2). Many of these concepts were first discussed in the book Organizations (March and Simon, 1958), and none of them has lost currency. Williamson developed bounded rationality into transaction cost theory and was early on attracted to the basic idea:

Bounded rationality seemed to me, then and since, as a useful way to go. James March's course in organization theory revealed that one did not need to think about organizations in classical (machine model) or fanciful (hyperrationality or nonrationality) terms but could address these matters in a behaviorally informed and scientific way. I learned about the behavioral theory of the firm from Richard Cyert - the famous Cyert and March (1963) being in the late stages of completion. (Williamson, 1996a, p. 351) 
The background for the Carnegie School was the Ford Foundation's mission to establish a broad and interdisciplinary behavioral social science in the late 1940s and early 1950s, and much of their efforts were directed at supporting the early set up of the Graduate School of Industrial Administration (GSIA) at Carnegie Mellon University (originally Carnegie Institute of Technology), where Simon, March and Cyert worked. The Carnegie Institute of Technology had been founded in 1912 by Andrew Carnegie and had established itself as one of the better engineering schools in the country. The early President Robert Doherty who had come from Yale wanted Carnegie Tech to be a leader in research and, hence, to break with the traditional mechanical engineering view of business education and include broader, social and interdisciplinary aspects. As a result of his ambitions, the first dean of what came to be known as the Graduate School of Industrial Administration (GSIA), George Leland Bach, was hired. Bach wanted to staff his department with economists who combined intellectual skills and experience in applying theory to real world situations and he wanted to put Carnegie at the forefront of US business schools. Simon, March and Cyert all came to Carnegie to help develop this view.

The behavioral group at Carnegie was embedded in a larger group of scholars, which included innovative economists such as Franco Modigliani, John Muth, Charles Holt, and Merton Miller. The spirit at Carnegie was that everybody interacted with everybody else; discussed each others' research and discussed science, so collaborative teams worked together as well as across each other's projects. Consisting of different people with different interests, these teams always worked together in a friendly way, despite different disciplines and despite varying degrees of admiration for the idea of rationality. It was an environment in which people were united by their deep and intense interest for doing science. The Carnegie school tried to develop the rudiments of process oriented understandings of how economic organization and decision making take place. They did so in an interdisciplinary way, linking economics to organization theory, cognitive science, sociology and psychology, and centering around concepts such as uncertainty, ambiguity, norms, routines, learning and satisficing. They used ideas from social science more broadly to advance understanding of economics and, in the process, contributed to the strands that came to be called behavioral economics (Day and Sunder, 1996). The 
ideas initiated by the Carnegie School helped to establish a foundation for modern ideas on bounded rationality, adaptive and evolutionary economics, and transaction cost theory, among other areas. According to Williamson, Carnegie was an 'enormously exciting' environment, in which organization theory served as linking theory to real problems (without loss of discipline) and in which behavioral economics existed 'cheek by jowl ${ }^{\text {‘ }}$ with rational expectation theory (1996a, p. 353). Williamson’s dissertation grew out of the Ford Foundation project on 'A Behavioral Theory of the Firm' (see below) and was on the economics of managerial discretion.

\section{Key ideas and Theories}

The behavioral research of Simon, Cyert and March aimed at making understandable how individuals make decisions and behave in the real world. They found that neoclassical economics gave too little attention to the institutional and cognitive constraints on economic and organizational behavior and on individual decisions, and too little room for human mistakes, foolishness, the complications of limited attention and other results of bounded rationality. As a result, they proposed to include the whole range of limitations on human knowledge and human computation that prevent organizations and individuals in the real world from behaving in ways that approximate the predictions of neoclassical theory. For example, decision makers are sometimes confronted by the need to optimize several, sometimes incommensurable, goals (Cyert and March, 1963). Furthermore, instead of assuming a fixed set of alternatives among which a decision maker chooses, the Carnegie School postulated a process for generating search and alternatives and analyzing decision processes through the idea of aspiration levels (March and Simon, 1958), a process that is regulated in part by variations in organizational slack (Cyert and March, 1963). Finally, individuals and organizations often rely on routines or rules of thumb learned from experience or from others, rather than seek to calculate the consequences of alternatives.

One of the first major results of the Carnegie School's work was a propositional inventory of organization theory, involving Herbert Simon, James March and Harold Guetzkow which led to the book Organizations (March and Simon, 1958). The book was intended to provide the inventory of knowledge of the (then almost non existing) field of 
organization theory, and also a more proactive role in defining the field. Results and insights from studies of organizations in political science, sociology, economics, and social psychology were summarized and codified. The book expanded and elaborated ideas on behavioral decision making, search and aspiration levels and elaborated the idea on the significance of organizations as social institutions in society. 'The basic features of organization structure and function', March and Simon wrote, 'derive from the characteristics of rational human choice. Because of the limits of human intellective capacities in comparison with the complexities of the problems that individuals and organizations face, rational behavior calls for simplified models that capture the main features of a problem without capturing al its complexities' (March and Simon, 1958, p. 151). March and Simon also wanted to unite empirical data-gathering research with rigorous theorizing in order to create a rigorous empirical theory that could organize and so give meaning to empirical facts with legitimate theory. Science, they believed, was the product of the organization of empirical facts into conceptual schemes, and the progress of science was based on the development of more sophisticated and elegant theoretical systems, but not necessarily the discovery of new facts.

The Ford Foundation also supported a larger project on behavioral theories of organizations which was carried out by Richard Cyert and James March (along with their students, including Julian Feldman, Edward Feigenbaum, William Starbuck - and Oliver Williamson). This project originated in the works of Cyert and March to developed improved models of oligopoly pricing by using organization theory. The research on the behavioral theory of the firm aimed at investigating how the characteristics of business firms as organizations affect important business decisions. Integrating theories of organizations with existing (mostly economic) theories of the firm, they developed an empirical theory rather than a normative one; and focused on classical problems in economics (such as pricing, resource allocation, and capital investment) to deal with the processes for making decisions in organizations.

At the center of 'A Behavioral Theory of the Firm' is the idea of the firm as an adaptive political coalition (Cyert and March, 1963), a coalition between different individuals and groups of individuals in the firm, each having different goals and hence the possibility of conflict of interest. Said Cyert and March: 'Since the existence of 
unresolved conflict is a conspicuous feature of organizations, it is exceedingly difficult to construct a useful positive theory of organizational decision-making if we insist on internal goal consistency. As a result, recent theories of organizational objectives describe goals as the result of a continuous bargaining-learning process. Such a process will not necessarily produce consistent goals' (Cyert and March, 1992, p. 28). The firm is therefore seen as an adaptive system that through learning and experimentation adapts to its environment. The experience of the firm is embodied in a number of standard operating procedures (for instance, solutions that have served the firm well in the past will be included in the organizational repertoire and will be easily reactivated in the face of similar problems in the future). As time passes and experience changes, so do standard operating procedures change through processes of search and learning. In other words, the firm is not an unchangeable entity - it is a system of rules, driven to change by current aspirations and targets reflecting experienced or anticipated dissatisfaction.

\section{Influence on TCE}

In several respects, Williamson's work and contributions to TCE are shaped by his Carnegie connection (Williamson, 1996, 2002), including the emphasis on the behavioral assumptions, on process, on adaptation, and on discrete structural analysis. ${ }^{1}$

\section{Behavioral assumptions}

From the outset, transaction cost economics has consciously been aware of the significance of the behavioral assumptions (contrary to much of neoclassical economics) (Williamson, 1996a, p. 55). This awareness reflects beyond any doubt that Williamson had been influenced by the behavioral economics group during his years at Carnegie, where discussion and questioning of the behavioral assumptions were an important part of the research. In particular, Williamson has adopted and elaborated the idea that people are 'intendedly rationality, but only limited so' (Williamson, 1985, p. 21), reflecting the influence of Herbert Simon's idea of bounded rationality. Another assumption of Williamson's program is the idea of opportunism; the conviction that people are 'selfinterest seeking with guile'. This assumption can be seen as reflecting Williamson's early (1963a, 1967) managerial theory of discretionary behavior where he tried to incorporate 
managerial objectives (maximization of private utility) into the neoclassical framework of the firm. Among the implications that follow from these behavioral assumptions are the existence of incomplete contracting and the importance of contractual trust (Williamson, 1996a, pp. 56-57).

\section{Process analysis}

The emphasis on process is yet another Carnegie idea, reflecting in particular ideas connected to Organizations (March and Simon, 1958) and A Behavioral Theory of the Firm (Cyert and March, 1963). ${ }^{2}$ Perhaps in particular consistent with Cyert and March’s view of the firm as a political coalition, Williamson has been cautious about excesses of managerial control (1996a, p. 226). Seeing the firm as a coalition among different individuals and groups of individuals in the firm, each having different goals, conflict of interest is a central idea. As Cyert and March notes: 'Since the existence of unresolved conflict is a conspicuous feature of organizations, it is exceedingly difficult to construct a useful positive theory of organizational decision-making if we insist on internal goal consistency. As a result, recent theories of organizational objectives describe goals as the result of a continuous bargaining-learning process. Such a process will not necessarily produce consistent goals' (Cyert and March, 1963, p. 28). The firm is seen as an adaptive system, which through learning, search and experimentation adapts to its environment. The experience of the firm is embodied in a number of 'standard operating procedures' (routines); procedures for solutions to problems which the firm in the past has managed to solve. As time passes by and experiences change, so do the firm's routines change through processes of organizational search and learning. As a result, the firm is seen not as a static entity, but as a system of rules, driven by its level of aspiration persistently being different from actual outcomes. Such a process view of organizations - including what Williamson refers to (1996a, p. 226) as intertemporal transformations - have important side effects such as producing the possibility of further bureaucratization of the organization (p. 228).

\section{Organizational Adaptation}


The theme of organizational adaptation also follows quite naturally from the behavioral theory of the firm (although Williamson combines this with Hayek's emphasis on spontaneous coordination of economic activities). Following March and Simon's (1958) idea that 'the basic features of organization structure and function derive from the characteristics of human problem solving and rational human choices' (p. 190), the organization is an adaptive entity which has evolved through a series of responses to people's decision making problems. But for Williamson the key idea is to combine spontaneous order in markets with intentional order in firms to yield a predictive theory of economic organization. Adaptations of both types are vital to a high performance system.

\section{Discrete Structural Analysis}

Williamson also sides with Simon (1978) when it comes to choosing the central mode of explanation. ${ }^{3}$ In keeping with the Carnegie perspective, Williamson sees the need for 'always study first-order (discrete structural) effects before examining second order (marginalist) refinements' (1996a, p. 232). Applying discrete, structural analysis is difficult to implement, for it relies on the idea that moves between organizational forms are attended by certain discontinuities (2000b, p. 14). Williamson sees the main differences between the organization of markets and firms as being a matter of incentive intensity, administrative control, contract law and adaptation (p. 15).

\section{Williamson Beyond Carnegie and Closing}

While Williamson went beyond Carnegie in his contributions and development of TCE (see for instance Williamson, 2002, 2004), he integrated the behavioral ideas with more 'rational' theories. For example, whereas Williamson's attempt to use the idea of organizational slack in his thesis, the 1970 book opened with the confession that '[s]ome will regard as paradoxical the fact that support for the neoclassical hypothesis should result from a study that has managerialist origins' (1970, p. xiii). Williamson sees the Mform innovation as an intentional response by management to overcome control loss in a large organization and to strengthen the profit orientation of management. He insists on bounded rationality throughout the book, but also sees the M-form as more consistent 
than the U-form with the neoclassical idea of maximization (1970, p. 134) and thus opts the M-form on efficiency grounds. After the publication of Corporate Control and Business Behavior, Williamson turned towards studying contracting practices. His 1971 paper on 'The Vertical Integration of Production' signaled a truly fundamental turn in the road. Rather than examine the firm as a production function, Williamson treated it as a governance structure - to be compared with markets for managing transactions. Rather than dealing with final goods and services, intermediate product markets came under examination. This reformulation of the vertical integration problem in transaction cost economizing terms became a paradigm problem, in that many other issues could be interpreted as variations on the very same contractual theme. The problems of writing interfirm contracts stem in part from the combination of bounded rationality and uncertainty. While the 1971 paper does mention bounded rationality (if only once), it became an important paper in featuring the hitherto neglected issue of unique assets although he doesn’t (yet) mention asset specificity. In such situations, bilateral dependency develops, indicating the need for long term contracts or vertical integration. Vertical integration is a response to contractual incompleteness and opportunism - which is very behavioral (in the Carnegie tradition). Williamson later argues that "transactions are assigned to and organized within governance structures in a discriminating (transaction-cost economizing) way” (1981, p. 1564). The focus on the transaction gradually became clear, and Williamson made in the early 1970s a distinction between transactional factors (such as small-numbers, uncertainty and information impactness) and human factors (bounded rationality, opportunism and organizational atmosphere) underlying vertical integration $(1971,1973,1974) .{ }^{4}$ These factors would explain the organization of economic activities and the degree of vertical integration.

Williamson also took steps towards making the transaction cost treatment of economic organization more general and to combine his institutional/transaction cost economics with aspects of contract law and organization theory to identify and explicate the key differences that distinguish forms of economic organization $(1983,1991)$. Beginning with his work on credible commitments (1983), Williamson emphasized the importance of credibility and the mechanisms which drives it, as these relate to the efficiency of economic organization. In 1991, he demonstrates that the different forms of 
economic organization are distinguished by different coordinating and control mechanisms and by different abilities to adapt to disturbances. Williamson's work on applying contract law to economic organization suggests (again) a middle-way between neoclassicism and a more behavioral approach, suggesting 'relational contracting' which is typically unenforceable in courts and dependent on arbitration and enforcement by private parties. Written as an 'ambitious effort to operationalize transaction cost economics' (Williamson, 1996a, p. 89), the 1991 paper also appeals to the interdisciplinary thinking that Williamson learned at Carnegie, and urges further developments along these lines (p. 119). This indicates that further integration of TCE and Carnegie ideas might be fruitful work in the future.

\section{Bibliography}

Cyert, R. and J.G. March (1963), A Behavioral Theory of the Firm, Second edition (1992), Oxford: Blackwell.

Day, R. and S. Sunder (1996), 'Ideas and Work of Richard M. Cyert', Journal of Economic Behavior and Organization, 31, 139-148.

Earl, P. (ed.) (1988), Behavioral Economics, Aldershot: Edward Elgar.

March, J.G. and H. A. Simon (1958), Organizations, Second edition (1993), Oxford: Blackwell.

Marschak, J. and R. Radner (1972), Economic Theory of Teams, New Haven: Oxford University Press.

Nelson, R. and S. Winter (1982), An Evolutionary Theory of Economic Change, Cambridge, Mass.: Bellknap Press.

Simon, H.A. (1978), Rationality as Process and Product of Thought, American Economic Review, 68, 1-16.

Williamson, O.E. (1963a), A Model of Rational Managerial Behavior, Chapter 9 of Cyert and March (1963).

Williamson, O.E. (1963b), Managerial Discretion and Business Behavior, American Economic Review, 53, 1032-1057.

Williamson, O. E. (1985), The Economic Institutions of Capitalism, New York: Free Press. 
Williamson, O.E. (1996a), The Mechanisms of Governance, Oxford: Oxford University

Press.

Williamson, O. (1996b), Transaction cost economics and the Carnegie Connection, Journal of Economic Behavior and Organization, 31, 149-155

Williamson, O.E. (2002): Empirical Microeconomics: Another Perspective. In Mie

Augier and James March, eds. The Economics of Choice, Change and Organization, Brookfield, VT. Edward Elgar.

Williamson, O.E. 2004. Herbert Simon and Organization Theory. In Mie Augier and James March, eds., Models of a Man: Essays in Memory of Herbert A. Simon, Cambridge, MA: MIT Press, 2004, pp. 279-295.:

\section{Notes}

1 Additionally, Williamson (1996a, p. 229) mentions also the issue of politics and of embeddedness and networks, and in (2002) he also mentions near-decomposability and weak-form selection as being part of the Carnegie contributions upon which his work rests; and the importance of reality testing.

2 Cyert and March, in the epilogue to the second edition of the Behavioral Theory of the Firm, acknowledge Williamson's program as being 'broadly consistent' with their own work (Cyert \& March, 1992, pp. 219-220), referring to Williamson's use of opportunism and bounded rationality. But whereas Williamson later featured the idea on bounded rationality more prominently, he talks in his early work about 'rational managerial behavior', defending the idea of maximization (of utility functions that include other things than profits). Williamson notes that profit maximization works only in cases with strong competition and warns against 'uncritical' application of the assumption of profit maximization in cases where competition is weak (1963a, p. 238). But the real crux of his thesis is the idea that maximization can be defended on other grounds as well, namely through the assumption of self-interest (p. 239). Thus, managers in Williamson's theory are not maximizing profits, but managerial self-interest. Williamson calls his model of managerial behavior 'behavioral' and summarizes its properties as including that his model uses the same basic assumption of rationality as mainstream economics - people are self-interest seeking and that under certain conditions, his model converges to the profit maximization hypothesis (p. 252).

3 Simon (1978) was introducing the term 'discrete structural analysis' into organizational economics in the following way: 'As economics expands beyond its central core of price theory, and its central concern with quantities of commodities and money, we observe in it ... [a] shift from a highly quantitative analysis, in which equilibration at the margin plays a central role, to a much more qualitative institutional analysis, in which discrete structural alternatives are compared' (p. 6).

4 Although references to Simon in the 1973 paper are missing, Williamson defines bounded rationality as referring to 'the rate and storage limits on the capacities of individuals to receive, store, retrieve, and process information without error' (p. 317). 